\title{
Implementation of Project-Based-Learning (PBL) Approach for Bioinformatics Laboratory Course
}

\author{
Sharanappa Achappa ${ }^{1}$, L.R.Patil ${ }^{2}$, \\ V.S.Hombalimath ${ }^{3}$, Anil R. Shet ${ }^{4}$ \\ ${ }^{1}$ sharanappaa@kletech.ac.in, ${ }^{2}$ lrpatil@kletech.ac.in, \\ ${ }^{3}$ hombalimath@kletech.ac.in, ${ }^{4}$ anil_shet@kletech.ac.in \\ 1, 2, 3 \&4 Department of Biotechnology, KLE Technological \\ University, Hubballi- 580 031, India.
}

\begin{abstract}
:
Bioinformatics is an interdisciplinary field involving biology, computer science, mathematics \& statistics concerned with the development $\&$ application of computer hardware\& software to acquire, storage, analysis \& visualization of biological information to draw a meaningful conclusion. This interdisciplinary nature makes bioinformatics an ideal framework to experience students the interplay between different scientific areas, while touching on societal aspects mainly on health and environment. Implementing Project-based learning (PBL) in Bioinformatics laboratory promoted students involving in experiential learning and critical thinking through group activities, improves problem analyzing and solving skills, bridge the gap between teaching and understanding the course, concentrate on the fundamentals and its application etc. This paper presents the experience with PBL implementation for $\mathrm{V}$ semester students in Bioinformatics laboratory course. An open ended problem on different diseases was floated to the group (group comprising up to 4 students, maximum 4 groups in a batch). Cascade of laboratory experiments were performed to understand the molecular aspect of protein involved in pathogenesis. The activity was instrumental in addressing graduate attributes namely: problem identification \& solving, identification of proper tools, data analysis and interpretation, communication skill and ability to work in teams were the major outcomes of this course. Rubrics-based assessment was performed to measure the attainment. Overall results show that the students were engaged in active learning and their understanding of the subject was enhanced.
\end{abstract}

Key words: PBL, Bioinformatics, Pathogenesis.

\section{Corresponding Author}

Sharanappa Achappa, Assistant Professor, Department of Biotechnology, KLE Technological University, Hubballi580 031. India.

E-mail: sharanappaa@kletech.ac.in

\section{Introduction}

Bioinformatics is an interdisciplinary field involving biology, computer science, mathematics \& statistics concerned with the development $\&$ application of computer hardware\& software to acquire, storage, analysis \& visualization of biological information to draw a meaningful conclusion [1]. This interdisciplinary nature makes bioinformatics an ideal framework to experience students the interplay between different scientific areas, while touching on societal aspects mainly on health and environment.

In the beginning of the genomics era, bioinformatics was mainly concerned with the creation and maintenance of databases to store biological information. More recently, emphasis has shifted towards the questions of how to analyze large data sets, particularly those stored in different formats in different databases. Ultimately, however, integration is needed [8] in order to form a comprehensive picture of normal cellular and subcellular activities, so that researchers may study how these activities are globally regulated.

Teaching bioinformatics is an interesting and challenging task because it requires in-depth knowledge of different disciplinary areas. So courses in bioinformatics often need to be planned and taught by academics, who have widely different formal training. This, in turn, poses not only challenges, but also opportunities for the development of novel teaching strategies [7].

Project based learning (PBL) is an approach, where the students are actively involved in the learning process through investigations [2]. The essential components of a PBL are the problem around which the students orient their investigations, and the series of activities associated with the investigations. Students, in groups, identify the learning issues and work together to find meaningful solutions [3]. The activities involved in the PBL drives learning by doing, rather than just listening [4].

In PBL, instruction is executed based on independent learning, practical studies and problem solving sessions performed under the supervision of an instructor/mentor especially in small groups [9]. In this process, real life 
problems or societal problems which increase curiosity and motivation of the students are given [9]. In PBL, teachers are named as instructor/mentor, and do the cognitive guidance and counseling duty during the process by selecting problems and channelizing the students to struggle with themselves [9].

The main purpose of implementing PBL were to: (1) improve the basic concept of understanding on learning innovation and development among students, (2) improve student's competence in writing scientific papers in the form of research proposal, (3) improve the student's ability to execute and communicate the result of the research, (4) know the student's responses towards the application of Project Based Learning [10].

Implementing Project-based learning (PBL) in Bioinformatics laboratory promoted students involving in experiential learning and critical thinking through group activities, improves problem analyzing and solving skills, bridge the gap between teachings and understanding the course, concentrate on the fundamentals and its application etc.

This paper presents the experience with PBL implementation for $\mathrm{V}$ semester Biotechnology students in Bioinformatics laboratory course. An open ended problem on different diseases was floated to the groups (group comprising up to 4 students, maximum 4 groups in a batch). Cascade of laboratory experiments were performed to understand the molecular aspect of protein involved in pathogenesis. The activity was instrumental in addressing graduate attributes namely: problem identification \& solving, identification of proper tools, data analysis and interpretation, communication skill and ability to work in teams were the major outcomes of this course.

\section{Methods}

A. Course Description:

Bioinformatics is the science concerned with the development \& application of computer hardware \& software to acquire, storage, analysis \& visualization of biological information to draw a meaningful conclusion. Bioinformatics laboratory course mainly focuses on retrieval, storage and analysis of biological data at sequence level. The main aim of this course is to train students extensively to develop hands-on skills in the use of bioinformatics tools and databases for analysis of biological information, wherein students understand and appreciate the enormous potential of bioinformatics in the contemporary life sciences. Expected outcomes include:

- Explain basics of bioinformatics and its application and able to know various databases and different softwares.

- Select the statistical method of sequence alignment to perform sequence similarity search for various biotechnological applications
- Describe various methods of phylogenetic analysis to obtain evolutionary relationship between organisms.

- Explain various statistical tools for prediction of structure and function of different biomolecules at gene level.

- Explain various statistical tools for prediction of structure and function of different biomolecules at protein level.

- Evaluate various tools to perform drug design used in treatment of various diseases.

- Design industrial application of bioinformatics in Drug discovery and Genome analysis for treating infectious diseases and submit a report and demonstrate effective oral communication.

B. Design of Bioinformatics Laboratory:

The Bioinformatics Laboratory was designed taking into consideration the inputs from industry stake-holders. The Laboratory experiments were categorized into four categories (Demonstration, Exercise, Structured Enquiry and Open Ended Experiment) as shown in table 1. With this, Bioinformatics laboratory was framed to address different PI's as shown in the assessment section.

Table 1. Categorization of Bioinformatics lab with rubrics parameter

\begin{tabular}{|c|c|c|c|}
\hline $\begin{array}{l}\text { Expt. } \\
\text { No. }\end{array}$ & Name of the Experiment & Type & $\begin{array}{l}\text { Rubrics } \\
\text { Parameters }\end{array}$ \\
\hline 1 & $\begin{array}{l}\text { Searching bibliographic } \\
\text { database for relevant } \\
\text { information }\end{array}$ & Demonstration & $\begin{array}{l}\text { 1.Conduct of } \\
\text { experiment }\end{array}$ \\
\hline 2 & $\begin{array}{l}\text { Searching sequence and } \\
\text { retrieve from nucleic acid } \\
\text { and Protein sequence } \\
\text { database }\end{array}$ & \multirow[t]{6}{*}{ Exercise } & \multirow{6}{*}{$\begin{array}{l}\text { 1.Conduct of } \\
\text { experiment } \\
\text { 2.Data Collection } \\
\text { \& representation } \\
\text { 3.Analysis of data } \\
\text { 4.Interpretation of } \\
\text { data } \\
\text { 5.Verification \& } \\
\text { conclusion } \\
\text { 6. Write up }\end{array}$} \\
\hline 3 & $\begin{array}{l}\text { PDB: Protein Data Bank } \\
\text { and structure visualization }\end{array}$ & & \\
\hline 4 & $\begin{array}{l}\text { Pair wise alignment of the } \\
\text { sequences }\end{array}$ & & \\
\hline 5 & $\begin{array}{l}\text { Searching sequence } \\
\text { database using BLAST } \\
\text { and FASTA algorithm }\end{array}$ & & \\
\hline 6 & $\begin{array}{l}\text { Multiple } \quad \text { Sequence } \\
\text { Alignment: CLUSTALW }\end{array}$ & & \\
\hline 7 & $\begin{array}{l}\text { Evolutionary Relationship/ } \\
\text { Phylogenetic Analysis }\end{array}$ & & \\
\hline 8 & Gene structure Prediction & \multirow[t]{3}{*}{$\begin{array}{l}\text { Structured } \\
\text { Enquiry }\end{array}$} & \multirow{3}{*}{$\begin{array}{l}\text { 1.Identification of } \\
\text { problem. } \\
\text { 2.Identification of } \\
\text { tools/parameter } \\
\text { 3. Selection of } \\
\text { procedure }\end{array}$} \\
\hline 9 & $\begin{array}{l}\text { Protein Secondary } \\
\text { Structure Prediction }\end{array}$ & & \\
\hline 10 & $\begin{array}{l}\text { Pattern searching in } \\
\text { proteins }\end{array}$ & & \\
\hline 11 & $\begin{array}{l}\text { Define gene structure and } \\
\text { design primers specific to } \\
\text { the identified gene of } \\
\text { microorganisms and draw } \\
\text { restriction digestion map } \\
\text { for sequence identified }\end{array}$ & $\begin{array}{l}\text { Open Ended } \\
\text { Experiment }\end{array}$ & $\begin{array}{l}\text { 1.Define complex } \\
\text { open ended } \\
\text { problem } \\
\text { Identification of } \\
\text { parameters } \\
\text { 2.Selection of } \\
\text { procedure } \\
\end{array}$ \\
\hline
\end{tabular}

C. Execution of Bioinformatics Laboratory: 
The present study was conducted for $\mathrm{V}$ semester undergraduate students of engineering in Biotechnology for Bioinformatics Laboratory. An open ended problem on different diseases was floated to the groups. Cascade of laboratory experiments were performed to understand the molecular aspect of protein involved in pathogenesis. The activity was instrumental in addressing graduate attributes namely: problem identification \& solving, identification of proper tools, data analysis and interpretation, communication skill and ability to work in teams were the major outcomes of this course.

The laboratory comprises structural and functional characterization of proteins involved in pathogenesis of microorganism. The Bioinformatics Laboratory was executed in two modules as represented in fig.1.

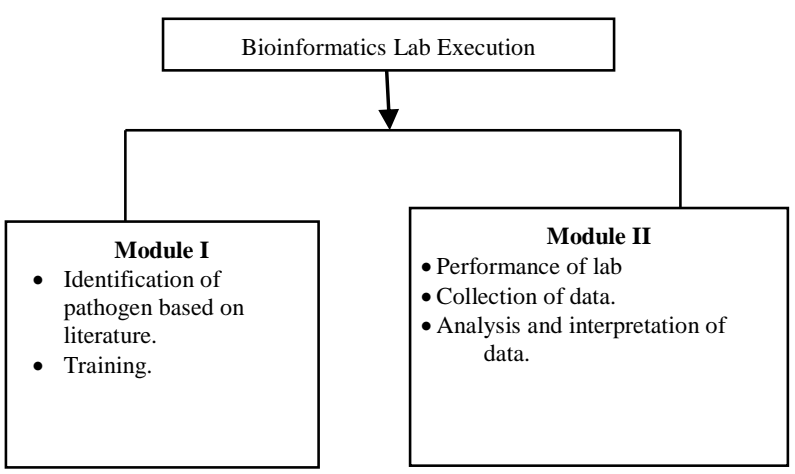

Fig.1 Modules of Bioinformatics Lab

In module-I, based on the literature survey, each student group identified four different pathogens based on the criteria adopted. Criteria adopted as: 1) Four pathogens: 2 bacterial, 1 fungal and 1 viral, 2) At least one pathogen should be regional specific. Training on ligand database and drug designing tools was given, which were not a part of regular lab.

In module-II, all laboratory experiments were performed as cascade for the identified protein of the identified pathogen. Analysis and interpretation of the results was performed for the protein to understand its relationship for the pathogenesis of the microorganism.

D. Assessment of the Bioinformatics Laboratory:

Rubrics-based assessment was practiced for all the experiments of the lab as shown below.

1) Demonstration: In demonstration experiment, working principle and demonstration of literature database was given to students. In this experiment the assessment parameters considered is conduct of experiment (PI Code: 4.1.3). Demonstration experiment was evaluated for 5 marks out of 80 marks.

2) Exercise Experiments: The assessment parameters considered were Conduct of experiment (PI Code: 4.1.3),
Data Collection \& representation (PI Code: 4.3.1), Analysis of data (PI Code: 4.3.2), Interpretation of data (PI Code: 4.1.4), Verification \& conclusion (PI Code: 4.3.4), Write up (PI Code: 10.1.2). Six exercise experiments were evaluated for 30 marks out of 80 marks. Rubrics for assessment of demonstration and exercise experiments are as follows:

Table 2. Rubrics for Demonstration and Exercise experiments

\begin{tabular}{|c|c|c|c|c|}
\hline $\begin{array}{l}\text { Rubrics } \\
\text { parameter }\end{array}$ & $\begin{array}{l}\text { Inadequate } \\
\text { (up to 25\%) }\end{array}$ & $\begin{array}{l}\text { Average (up } \\
\text { to 50\%) }\end{array}$ & $\begin{array}{l}\text { Admirable } \\
\text { /Good (up to } \\
75 \% \text { ) }\end{array}$ & $\begin{array}{l}\text { Outstanding } \\
\text { (up to 100\%) }\end{array}$ \\
\hline $\begin{array}{l}\text { Conduct of } \\
\text { experiment }\end{array}$ & $\begin{array}{l}\text { Inadequate } \\
\text { quality of } \\
\text { experimental } \\
\text { work. }\end{array}$ & $\begin{array}{l}\text { Experiment } \\
\mathrm{s} \text { were } \\
\text { conducted. }\end{array}$ & $\begin{array}{l}\text { Adequate } \\
\text { conduct of } \\
\text { experiment }\end{array}$ & $\begin{array}{l}\text { Proper } \\
\text { conduct of } \\
\text { experiment }\end{array}$ \\
\hline $\begin{array}{l}\text { Data } \\
\text { Collection } \\
\text { \& } \\
\text { representati } \\
\text { on }\end{array}$ & $\begin{array}{l}\text { Raw data, } \\
\text { including } \\
\text { units, are not } \\
\text { recorded in a } \\
\text { way that is } \\
\text { appropriate } \\
\text { and clear. } \\
\text { The title of } \\
\text { the data table } \\
\text { is not } \\
\text { included. } \\
\text { Data notatio } \\
\text { representatio } \\
\text { n is not } \\
\text { according to } \\
\text { the format } \\
\text { and not at all } \\
\text { clear for } \\
\text { analysis }\end{array}$ & $\begin{array}{l}\text { Raw data, } \\
\text { including } \\
\text { units, are } \\
\text { recorded } \\
\text { although } \\
\text { not as } \\
\text { clearly or } \\
\text { appropriatel } \\
\text { y as they } \\
\text { might be. } \\
\text { The title of } \\
\text { the data } \\
\text { table is not } \\
\text { included. } \\
\text { Data } \\
\text { representati } \\
\text { on is per } \\
\text { the format } \\
\text { with some } \\
\text { some } \\
\text { logical } \\
\text { error and } \\
\text { not clear for } \\
\text { analysis }\end{array}$ & $\begin{array}{l}\text { Raw data, } \\
\text { including } \\
\text { units, are } \\
\text { recorded } \\
\text { although } \\
\text { not as } \\
\text { clearly or } \\
\text { appropriatel } \\
\text { y as they } \\
\text { might be. } \\
\text { The title of } \\
\text { the data } \\
\text { table is } \\
\text { included. } \\
\text { Data } \\
\text { representati } \\
\text { on is per } \\
\text { the format } \\
\text { required } \\
\text { and not so } \\
\text { clear for } \\
\text { analysis }\end{array}$ & $\begin{array}{l}\text { Raw data, } \\
\text { including } \\
\text { units, are } \\
\text { recorded in } \\
\text { a way that } \\
\text { is } \\
\text { appropriate } \\
\text { and clear. } \\
\text { The title of } \\
\text { the data } \\
\text { table is } \\
\text { included. } \\
\text { Data } \\
\text { representati } \\
\text { on is per } \\
\text { the format } \\
\text { required } \\
\text { and clear } \\
\text { for analysis }\end{array}$ \\
\hline $\begin{array}{l}\text { Analysis of } \\
\text { data }\end{array}$ & $\begin{array}{l}\text { Data are } \\
\text { presented in } \\
\text { ways (charts, } \\
\text { tables, } \\
\text { graphs) that } \\
\text { are very } \\
\text { unclear. } \\
\text { Error } \\
\text { analysis is } \\
\text { not included. }\end{array}$ & $\begin{array}{l}\text { Data are } \\
\text { presented in } \\
\text { ways } \\
\text { (charts, } \\
\text { tables, } \\
\text { graphs) that } \\
\text { can be } \\
\text { understood } \\
\text { and } \\
\text { interpreted, } \\
\text { although } \\
\text { not as } \\
\text { clearly as } \\
\text { they might } \\
\text { be. Error } \\
\text { analysis is } \\
\text { not } \\
\text { included. }\end{array}$ & $\begin{array}{l}\text { Data are } \\
\text { presented in } \\
\text { ways } \\
\text { (charts, } \\
\text { tables, } \\
\text { graphs) that } \\
\text { can be } \\
\text { understood } \\
\text { and } \\
\text { interpreted, } \\
\text { although } \\
\text { not as } \\
\text { clearly as } \\
\text { they might } \\
\text { be. Error } \\
\text { analyses are } \\
\text { included } \\
\text { but not } \\
\text { clear. }\end{array}$ & $\begin{array}{l}\text { Data are } \\
\text { presented in } \\
\text { ways } \\
\text { (charts, } \\
\text { tables, } \\
\text { graphs) that } \\
\text { best } \\
\text { facilitate } \\
\text { understandi } \\
\text { ng and } \\
\text { interpretatio } \\
\text { n. Error } \\
\text { analysis is } \\
\text { included. }\end{array}$ \\
\hline
\end{tabular}




\begin{tabular}{|c|c|c|c|c|}
\hline $\begin{array}{l}\text { Interpretati } \\
\text { on of data }\end{array}$ & $\begin{array}{l}\text { The results } \\
\text { are not } \\
\text { interpreted in } \\
\text { a logical } \\
\text { way. The } \\
\text { limitations } \\
\text { and } \\
\text { weaknesses } \\
\text { are not } \\
\text { discussed, } \\
\text { nor are } \\
\text { suggestions } \\
\text { made as to } \\
\text { how to limit } \\
\text { or eliminate } \\
\text { them. }\end{array}$ & $\begin{array}{l}\text { The results } \\
\text { are } \\
\text { interpreted } \\
\text { but not } \\
\text { clear. The } \\
\text { limitations } \\
\text { and } \\
\text { weaknesses } \\
\text { are } \\
\text { discussed } \\
\text { with no } \\
\text { suggestions }\end{array}$ & $\begin{array}{l}\text { The results } \\
\text { are } \\
\text { interpreted, } \\
\text { but not as } \\
\text { fully as } \\
\text { they might } \\
\text { be. The } \\
\text { limitations } \\
\text { and } \\
\text { weaknesses } \\
\text { are } \\
\text { discussed, } \\
\text { but few or } \\
\text { no } \\
\text { suggestions } \\
\text { are made as } \\
\text { to how to } \\
\text { limit or } \\
\text { eliminate } \\
\text { them. }\end{array}$ & $\begin{array}{l}\text { The results } \\
\text { are fully } \\
\text { interpreted. } \\
\text { The } \\
\text { limitations } \\
\text { and } \\
\text { weaknesses } \\
\text { are } \\
\text { discussed } \\
\text { and } \\
\text { suggestions } \\
\text { are made as } \\
\text { to how to } \\
\text { limit or } \\
\text { eliminate } \\
\text { them. }\end{array}$ \\
\hline Conclusion & $\begin{array}{l}\text { Conclusion } \\
\text { is not } \\
\text { addressed. }\end{array}$ & $\begin{array}{l}\text { Conclusion } \\
\text { is not } \\
\text { clearly } \\
\text { addressed. }\end{array}$ & $\begin{array}{l}\text { Conclusion } \\
\text { is not so } \\
\text { clear as it } \\
\text { should be. }\end{array}$ & $\begin{array}{l}\text { Conclusion } \\
\text { is clearly } \\
\text { represented. }\end{array}$ \\
\hline $\mathbf{W}$ & $\begin{array}{l}\text { Report contai } \\
\text { ns many } \\
\text { distracting } \\
\text { mistakes, } \\
\text { making it } \\
\text { generally } \\
\text { difficult to } \\
\text { follow and } \\
\text { poorly } \\
\text { organized. } \\
\text { Figures, and } \\
\text { tables are } \\
\text { graph are } \\
\text { hard understand, } \\
\text { und are not } \\
\text { and } \\
\text { adequate to } \\
\text { link to text. }\end{array}$ & $\begin{array}{l}\text { Report is } \\
\text { generally } \\
\text { clear, but } \\
\text { distracting } \\
\text { errors and } \\
\text { flow make } \\
\text { it difficult } \\
\text { to follow at } \\
\text { times and } \\
\text { organizatio } \\
\text { n of report } \\
\text { is weak. } \\
\text { Figures, } \\
\text { tables and } \\
\text { graph are } \\
\text { hard to } \\
\text { understand, } \\
\text { are not all } \\
\text { linked to } \\
\text { text. } \\
\text { Several } \\
\text { need } \\
\text { improveme } \\
\text { nt. }\end{array}$ & $\begin{array}{l}\text { Report is } \\
\text { logical and } \\
\text { easy to } \\
\text { read, and } \\
\text { may } \\
\text { contain } \\
\text { a few errors } \\
\text { causing } \\
\text { minimal } \\
\text { reader } \\
\text { distraction } \\
\text { and } \\
\text { organized } \\
\text { strongly. } \\
\text { All figures, } \\
\text { tables and } \\
\text { graphs can } \\
\text { be } \\
\text { understood } \\
\text { with } \\
\text { information } \\
\text { given and } \\
\text { are linked } \\
\text { to text. }\end{array}$ & $\begin{array}{l}\text { Report is } \\
\text { virtually } \\
\text { error-free, } \\
\text { and } \\
\text { contains } \\
\text { few if any } \\
\text { reader } \\
\text { distractions } \\
\text { and clearly } \\
\text { organized } \\
\text { with } \\
\text { excellent } \\
\text { transitions. } \\
\text { All figures, } \\
\text { tables and } \\
\text { graphs are } \\
\text { easy to } \\
\text { understand, } \\
\text { and are } \\
\text { clearly } \\
\text { linked to } \\
\text { the text. }\end{array}$ \\
\hline
\end{tabular}

3) Structured Enquiry Experiments: The experiments were assessed by considering the following rubrics parameter Identification of problem (PI Code: 4.1.1), Identification of tools (PI Code:4.1.2), Selection of procedure (PI Code:4.1.2). Three structured enquiry experiments were evaluated for 30 marks. Rubrics for structured enquiry experiments considered for assessment are as follows:
Table 3. Rubrics for Structural Enquiry Experiments

\begin{tabular}{|c|c|c|c|c|}
\hline $\begin{array}{l}\text { Rubrics } \\
\text { parameter }\end{array}$ & $\begin{array}{l}\text { Inadequate } \\
\text { (up to 25\%) }\end{array}$ & $\begin{array}{l}\text { Average (up } \\
\text { to 50\%) }\end{array}$ & $\begin{array}{l}\text { Admirable } \\
\text { /Good (up to } \\
75 \% \text { ) }\end{array}$ & $\begin{array}{l}\text { Outstanding } \\
\text { (up to } \\
100 \% \text { ) }\end{array}$ \\
\hline $\begin{array}{l}\text { Identificatio } \\
\text { n of } \\
\text { Problem }\end{array}$ & $\begin{array}{l}\text { Identified } \\
\text { no } \\
\text { parameters } \\
\text { with no } \\
\text { reference to } \\
\text { the } \\
\text { literature }\end{array}$ & $\begin{array}{l}\text { Parameters } \\
\text { identified } \\
\text { but not } \\
\text { clearly } \\
\text { related to } \\
\text { the } \\
\text { experiment } \\
\text { s with very } \\
\text { little } \\
\text { reference to } \\
\text { the } \\
\text { literature. }\end{array}$ & $\begin{array}{l}\text { Parameter } \\
\text { identified } \\
\text { but not } \\
\text { clearly } \\
\text { correlates } \\
\text { to the } \\
\text { experiment } \\
\text { al setup } \\
\text { with } \\
\text { reference to } \\
\text { literature. }\end{array}$ & $\begin{array}{l}\text { Parameters } \\
\text { identified } \\
\text { according } \\
\text { to the } \\
\text { experiment } \\
\text { al setup } \\
\text { with clear } \\
\text { reference to } \\
\text { literature. }\end{array}$ \\
\hline $\begin{array}{l}\text { Identi } \\
\text { of par }\end{array}$ & $\begin{array}{l}\text { Identified no } \\
\text { parameters } \\
\text { with no } \\
\text { reference to } \\
\text { the literature }\end{array}$ & $\begin{array}{l}\text { Parameters } \\
\text { identified but } \\
\text { not clearly } \\
\text { related to the } \\
\text { experiments } \\
\text { with very } \\
\text { little reference } \\
\text { to the } \\
\text { literature. }\end{array}$ & $\begin{array}{l}\text { Parameter } \\
\text { identified but } \\
\text { not clearly } \\
\text { correlates to } \\
\text { the } \\
\text { experimental } \\
\text { setup with } \\
\text { reference to } \\
\text { literature. }\end{array}$ & $\begin{array}{l}\text { Parameters } \\
\text { identified } \\
\text { according to } \\
\text { the } \\
\text { experimental } \\
\text { setup with } \\
\text { clear } \\
\text { reference to } \\
\text { literature. }\end{array}$ \\
\hline $\begin{array}{l}\text { Selection of } \\
\text { Bioinformat } \\
\text { ics tools }\end{array}$ & $\begin{array}{l}\text { Demonstrat } \\
\text { ed little or } \\
\text { no ability } \\
\text { to conduct } \\
\text { experiment } \\
\text { s. } \\
\text { Did not } \\
\text { collect } \\
\text { Meaningful } \\
\text { data. }\end{array}$ & $\begin{array}{l}\text { Demonstrat } \\
\text { ed some } \\
\text { ability to } \\
\text { conduct } \\
\text { experiment } \\
\text { s. } \\
\text { Collected } \\
\text { some } \\
\text { Meaningful } \\
\text { data. }\end{array}$ & $\begin{array}{l}\text { Demonstrat } \\
\text { ed } \\
\text { adequate } \\
\text { ability to } \\
\text { conduct } \\
\text { Experiment } \\
\text { s. } \\
\text { Collected } \\
\text { most of the } \\
\text { needed } \\
\text { data. }\end{array}$ & $\begin{array}{l}\text { Demonstrat } \\
\text { ed superior } \\
\text { ability to } \\
\text { conduct } \\
\text { experiment } \\
\text { s. } \\
\text { Collected } \\
\text { all the } \\
\text { appropriate } \\
\text { data. }\end{array}$ \\
\hline
\end{tabular}

4) Open Ended Experiments: In Open Ended Experiment, final assessment was done by following rubric parameters: Define complex open ended problem (PI Code: 3.1.1, 3.1.2, 3.1.5), Selection of procedure (PI Code: 4.1.2). One open ended experiment was evaluated for 15 marks. Rubrics for structured enquiry experiments considered for assessment are as follows:

Table 4. Rubrics for Open Ended Experiment

\begin{tabular}{|c|c|c|c|c|}
\hline $\begin{array}{l}\text { Rubrics } \\
\text { parameter }\end{array}$ & $\begin{array}{l}\text { Inadequate } \\
\text { (up to 25\%) }\end{array}$ & $\begin{array}{l}\text { Average (up } \\
\text { to } 50 \% \text { ) }\end{array}$ & $\begin{array}{l}\text { Admirable } \\
/ \text { Good (up to } \\
75 \% \text { ) }\end{array}$ & $\begin{array}{l}\text { Outstanding } \\
\text { (up to } 100 \% \text { ) }\end{array}$ \\
\hline $\begin{array}{l}\text { Define } \\
\text { complex } \\
\text { open ended } \\
\text { problem }\end{array}$ & $\begin{array}{l}\text { No clear } \\
\text { objectives } \\
\text { were } \\
\text { determined } \\
\text { by no } \\
\text { reference to } \\
\text { the literature }\end{array}$ & $\begin{array}{l}\text { Design } \\
\text { objectives } \\
\text { were } \\
\text { determined } \\
\text { by stating } \\
\text { problem but } \\
\text { not clearly } \\
\text { related to the } \\
\text { experiments } \\
\text { with very } \\
\text { little reference } \\
\text { to the } \\
\text { literature. }\end{array}$ & $\begin{array}{l}\text { Design } \\
\text { objectives } \\
\text { were } \\
\text { determined } \\
\text { by stating } \\
\text { problem but } \\
\text { not clearly } \\
\text { correlate to } \\
\text { the lo } \\
\text { experiments } \\
\text { with little } \\
\text { reference to } \\
\text { the literature. }\end{array}$ & $\begin{array}{l}\text { Design } \\
\text { objectives } \\
\text { were } \\
\text { determined } \\
\text { by stating } \\
\text { problem } \\
\text { clearly } \\
\text { correlating to } \\
\text { the } \\
\text { experiments } \\
\text { with } \\
\text { reference to } \\
\text { the literature. }\end{array}$ \\
\hline
\end{tabular}




\section{Results}

PBL implementation in Bioinformatics lab aimed at strengthening the basic skill-sets of individual students. The analysis and interpretation skills were instrumental in addressing some of the program Outcomes (POs). Performance of the students during the lab indicated a thorough understanding of the concept learnt through experiential learning. Also, the evaluation process results indicated the involvement of the students in the group activity, their capability to work in groups and also technical contribution towards the project. Feedback from the students indicated that the students enjoyed the PBL activity. The table 5 illustrates the mapping of rubrics framed for assessment to the POs addressed.

Table 5. Mapping of Rubric Parameters with Performance Indicators

\begin{tabular}{|c|c|c|}
\hline $\begin{array}{l}\text { Rubrics } \\
\text { Parameters }\end{array}$ & PI Code & PI Addressed \\
\hline $\begin{array}{l}\text { Identification of } \\
\text { Problem/ } \\
\text { parameter }\end{array}$ & 4.1 .1 & $\begin{array}{l}\text { Define a problem to carry-out } \\
\text { investigation with its scope and } \\
\text { importance. }\end{array}$ \\
\hline $\begin{array}{l}\text { Selection } \\
\text { appropriate } \\
\text { procedure }\end{array}$ & 4.1 .2 & $\begin{array}{l}\text { Identify and apply relevant } \\
\text { experimental procedure /bioinformatics } \\
\text { tools /databases for a defined problem }\end{array}$ \\
\hline $\begin{array}{l}\text { Conduct } \\
\text { experiment }\end{array}$ & 4.1 .3 & $\begin{array}{l}\text { Use appropriate analytical instruments } \\
\text { /software tools to carry-out the } \\
\text { experiments }\end{array}$ \\
\hline $\begin{array}{l}\text { Data Collection \& } \\
\text { representation }\end{array}$ & 4.3 .1 & $\begin{array}{l}\text { Use appropriate procedures, tools and } \\
\text { techniques to collect and analyze data }\end{array}$ \\
\hline Analysis of data & 4.3 .2 & $\begin{array}{l}\text { Critically analyze data for trends and } \\
\text { correlations, stating possible errors and } \\
\text { limitations }\end{array}$ \\
\hline $\begin{array}{l}\text { Interpretation of } \\
\text { data }\end{array}$ & 4.1 .4 & $\begin{array}{l}\text { Correlate the experimental outcomes } \\
\text { with underlying theoretical concepts } \\
\text { and principles }\end{array}$ \\
\hline Conclusion & 4.3 .4 & $\begin{array}{l}\text { Synthesize information and knowledge } \\
\text { about the problem from the raw data to } \\
\text { reach appropriate conclusions }\end{array}$ \\
\hline Write up & 10.1 .2 & $\begin{array}{l}\text { Produce clear, well-constructed, and } \\
\text { well-supported written engineering } \\
\text { documents. }\end{array}$ \\
\hline \multirow{2}{*}{$\begin{array}{lr}\begin{array}{l}\text { Define } \\
\text { open }\end{array} & \text { complex } \\
\text { problem } & \text { ended }\end{array}$} & 3.1 .1 & $\begin{array}{l}\text { Recognize a problem statement that } \\
\text { assists in the design process }\end{array}$ \\
\hline & 3.1 .2 & $\begin{array}{l}\text { Identify and document the process / } \\
\text { system requirements }\end{array}$ \\
\hline
\end{tabular}

The attainment of Program Outcomes (PO) was evaluated by mapping the rubrics parameter with Performance Indicator (PI) as shown in the table 5. PI for different experiments was assessed as explained in methodology section based on the rubrics. Based on the mapping of rubric parameters with PI, \% attainment of various PI was measured and represented in Fig.2.

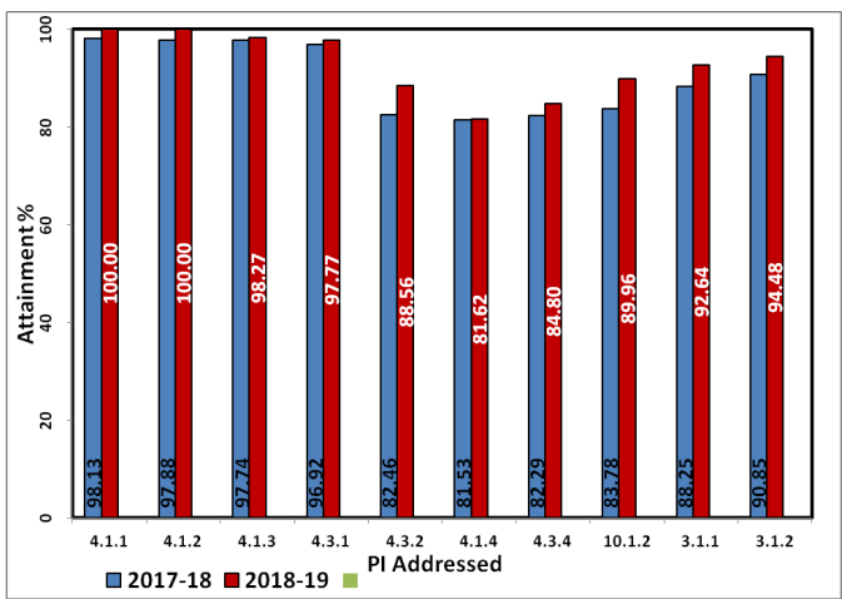

Fig.2: PI attainment for the academic year 2017-18 \& 2018-19

The attainment was highest (100\%) for PI 4.1.1 \& 4.1.2 which indicated that the students are good at identification of problem statement, selection of tools and conduct of experiments, while it was lowest $(81.62 \%, 84.80 \%$, $88.56 \%$ ) for PI \& 4.1.4,4.3.4 \& 4.3.2 respectively, which indicated the scope for enhancement in analysis and interpretation of data.

In the second cycle (Batch 2018-19) of implementation of PBL, 10 groups of students presented their work in International conference and also in the process of writing journal paper.

\section{Conclusion:}

Based on the experience of implementing PBL, we conclude that the students successfully demonstrated their ability in problem identification \& solving, identification of proper tools, data analysis and interpretation, communication skills and ability to work in teams. Attainment of PI clearly showed scope for improvement in area like analysis and interpretation of the data (measured by PI 4.3.2, 4.1.4 \& 4.3.4). Implementation of PBL also increased the research ability of the students which in turn resulted in 10 papers presented in international conference.

\section{Acknowledgment}

The authors thank Dr. Uday Muddapur, Head, Department of Biotechnology and all staff members of Biotechnology department, Dr. Ashok Shettar, Honorable ViceChancellor, KLE Technological University, Prof.B.L. Desai, Executive Dean, Dr. N.H. Ayachit, Registrar, KLE Technological University and Dr. P.G. Tewari, Principal, B.V. Bhoomaraddi College of Engineering and Technology, Hubballi for their constant encouragement and support. 


\section{References}

Yun-Can Ai, "Teaching bioinformatics: A studentcentred and problem based approach," The China Papers' Issue 1, October 2002, (2002).

Blumenfeld, P. C., Soloway, E., Marx, R. W.,Krajcik, J. S., guzdial, M., and Palincsar, A. (1991) Motivating Project-Based Learning: Sustaining the Doing, Supporting the Learning, Educational Psychologist, 26 (3\&4), 369-398.

Hmelo-Silver, C. E. (2004) Problem-based Learning: What and How Do Students Learn? Educational Psychology Review, 16 (3), 235-266.

Savege, R. N., Katherine, C. C., and Vanasupa, L.(2007) Integrating Project-based Learning throughout the Undergraduate Engineering Curriculum, Journal of STEM Education, 8(3-4), 15-27.

Ayas, K. \& Zeniuk, N. (2001) 'Project-Based Learning: Building Communities of Reflective Practitioners'. Management Learning, 32 (1). pp 61-76.

Barron, B. J. S., D. L. Schwartz, et al. (1998). "Doing With Understanding: Lessons From Research on Problem- and Project-Based Learning." Journal of the Learning Sciences 7(3-4): 271-311.

Ai,Y-C. (2002) The development of a Microbiology course for a large class of students of diverse backgrounds: A review of seven years of change in Zhongshan (Sun Yet-Sen) University, China. The China Papers: Tertiary Science and Mathematics Teaching for the 21st Century, 1, 36-41.

Chicurel, M. (2002) Bioinformatics: Bringing it all together. Nature, 419, 751-757.

Pinar Celika, Fatih Onderb, Ilhan Silaya,b,*(2011)The effects of problem-based learning on the students' success in physics course Procedia - Social and Behavioral Sciences 28 (2011) 656 - 660.

Suparti (2015); Project-Based Learning Guided Lesson Study Improve the Achievement of Learning Outcomes on Seminar Accounting Education Course at Department Of Accounting; Journal of Research \& Method in Education (IOSR-JRME) e-ISSN: 2320-7388,p-ISSN: 2320-737X Volume 5, Issue 3 Ver. II (May - Jun. 2015), PP 05-11. 